\title{
Electro-Spun $\mathrm{RuO}_{2}$ 나노선 지지체에 담지된 Pt촉매의 메탄올 Electro-Oxidation 특성
}

\author{
염용식 · 안효진 ${ }^{\dagger}$ \\ 서울과학기술대학교 신소재공학과
}

\section{Methanol Electro-Oxidation of Electro-Spun $\mathrm{RuO}_{2}$ Nanowire Supported Pt Catalysts}

\author{
Yong-Sik Yeom and Hyo-Jin Ahn ${ }^{\dagger}$ \\ Department of Materials Science and Engineering, Seoul National University of Science and \\ Technology, Seoul 139-743, Korea
}

(2011년 6월 14일 접수 : 2011년 7월 19일 최종수정 : 2011년 7월 22일 채택)

\begin{abstract}
Pt nanoparticle catalysts incorporated on $\mathrm{RuO}_{2}$ nanowire support were successfully synthesized and their electrochemical properties, such as methanol electro-oxidation and electrochemically active surface (EAS) area, were demonstrated for direct methanol fuel cells (DMFCs). After fabricating $\mathrm{RuO}_{2}$ nanowire support via an electrospinning method, two different types of incorporated $\mathrm{Pt}$ nanoparticle electrocatalysts were prepared using a precipitation method via the reaction with $\mathrm{NaBH}_{4}$ as a reducing agent. One electrocatalyst was $20 \mathrm{wt} \% \mathrm{Pt} / \mathrm{RuO}_{2}$, and the other was $40 \mathrm{wt} \% \mathrm{Pt} / \mathrm{RuO}_{2}$. The structural and electrochemical properties of the Pt nanoparticle electrocatalysts incorporated on electrospun $\mathrm{RuO}_{2}$ nanowire support were investigated using a bright field transmission electron microscopy (bright field TEM), X-ray diffraction (XRD), X-ray photoelectron spectroscopy (XPS), and cyclic voltammetry. The bright field TEM, XRD, and XPS results indicate that Pt nanoparticle electrocatalysts with sizes of approximately 2-4 nm were well incorporated on the electrospun $\mathrm{RuO}_{2}$ nanowire support with a diameter of approximately $50 \mathrm{~nm}$. The cyclic voltammetry results showed that the Pt nanoparticle catalysts incorporated on the electrospun $\mathrm{RuO}_{2}$ nanowire support give superior catalytic activity in the methanol electro-oxidation and a higher electrochemically active surface (EAS) area when compared with the electrospun Pt nanowire electrocatalysts without the $\mathrm{RuO}_{2}$ nanowire support. Therefore, the Pt nanoparticle catalysts incorporated on the electrospun $\mathrm{RuO}_{2}$ nanowire support could be a promising electrode for direct methanol fuel cells (DMFCs).
\end{abstract}

Key words electrocatalysts, electrospinning, nanowires, $\mathrm{RuO}_{2}$, methanol electro-oxidation.

\section{1. 서 론}

제한된 화석연료 매장량으로 인해 최근 유가 급등 같 은 상황이 전개되면서 석유 자원 확보와 더불어 지열, 수 력, 풍력, 태양광, 바이오매스, 전기화학 에너지 저장 및 변환 소자 등 다양한 신재생에너지에 대한 관심이 더욱 더 증가 되고 있다. 최근에 휴대폰에서부터 전기자동차에 이르기까지 고성능 전자기계의 발전은 고성능 에너지 저 장 및 변환 소자를 더욱 필요로 하고 있다. 그 중 연료 전지는 환경친화적이며 높은 에너지 전환효율이 내연소 엔 진에 비하여 우수하다. ${ }^{1,2)}$ 연료전지는 전해질, 작동온도, 연

\footnotetext{
${ }^{\dagger}$ Corresponding author

E-Mail : hjahn@seoultech.ac.kr (H. -J. Ahn)
}

료의 종류에 따라 인산형(Phosphoric Acid Fuel Cell, PAFC), 알카리형(Alkaline Fuel Cell, AFC), 용융탄산염 형(Molten Carbonate Fuel Cell, MCFC), 고체산화물형 (Solid Oxide Fuel Cell, SOFC), 고분자전해질형(Proton Exchange Membrane Fuel Cell, PEMFC), 직접메탄올형 (Direct Methanol Fuel Cell, DMFC)으로 분류되고 있다. ${ }^{3)}$ 이 중 직접메탄올 연료전지(DMFC)의 경우 고 에너지 밀 도, 낮은 작동온도, 연료의 처리가 쉬우며 환경친화적인 장 점들로 인하여 최근에 연구가 활발히 진행 되고 있다. ${ }^{4)}$ 직 접메탄올 연료전지(DMFC)의 식(1)과 같이 anode에서는 메 탄올을 물과 함께 반응하여 carbon dioxide, 6 protons, 6 electrons을 생산한다. cathode에서는 oxygen과 6 protons, 6 electrons이 반응하여 물을 생산한다. 직접메탄올 연료 전지의 전체 반응은 아래와 같다. ${ }^{1)}$ 
Anode: $\mathrm{CH}_{3} \mathrm{OH}+\mathrm{H}_{2} \mathrm{O} \rightarrow \mathrm{CO}_{2}+6 \mathrm{H}^{+}+6 \mathrm{e}^{-}$

Cathode: $3 / 2 \mathrm{O}_{2}+6 \mathrm{H}^{+}+6 \mathrm{e}^{-} \rightarrow 3 \mathrm{H}_{2} \mathrm{O}$

Overall reaction: $\mathrm{CH}_{3} \mathrm{OH}+3 / 2 \mathrm{O}_{2} \rightarrow \mathrm{CO}_{2}+2 \mathrm{H}_{2} \mathrm{O}$

직접메탄올 연료전지를 상용화하기 위해서는 anode에서 low electro-catalytic activity, fuel cross-over, 촉매의 제 한된 양과 높은 가격등과 같은 어려운 문제점들을 극복해 야 한다. ${ }^{4,5)}$ 그 중 가장 중요한 issue중의 하나는 methanol electro-oxidation의 catalytic activity을 향상 시키는 것이다. 이것을 이루기 위한 중요한 요소기술 중의 하나는 촉매의 활용을 높이고 촉매의 담지량을 감소 시키는 지지체를 사 용하는 것이다. 지금까지 CNT, Vulcan carbon, Graphene 와 같은 카본 기반의 지지체와 $\mathrm{RuO}_{2}, \mathrm{CeO}_{2}$ 와 같은 금속 산화물 기반 지지체들의 연구가 활발히 진행 되었다. ${ }^{6,7)}$ 최 근에 일차원 나노선에 대한 연구가 광학, 전자공학, 바이 오 진단학 및 에너지등 다양한 분야에서 꾸준한 관심을 받 고 있지만 직접메탄올 연료전지용 일차원 나노선 지지체 에 대한 연구는 아직도 많이 부족한 실정이다. ${ }^{8)}$

본 연구에서는 전기방사법을 이용하여 일차원의 $\mathrm{RuO}_{2}$ 나노선 지지체를 제조 하였으며 침전법을 이용하여 Pt 나 노 입자 촉매의 두 가지 다른 종류를 합성하였다. 하나는 $20 \mathrm{wt} \% \mathrm{Pt} / \mathrm{RuO}_{2}$ 이고 다른 하나는 $40 \mathrm{wt} \% \mathrm{Pt} / \mathrm{RuO}_{2}$ 나노선 촉매이다. 또한 일차원 전극촉매의 비교 평가를 위하여 전 기방사법을 이용한 electrospun Pt 나노선 전극촉매를 제조 하였다. 모든 샘플들은 methanol electro-oxidation와 electrochemically active surface (EAS) area 같은 전기화학적 성 능을 비교 평가하였고 bright-field TEM, XRD, XPS를 이용하여 구조, 형태, 성분들을 분석하였다.

\section{2. 실험 방법}

\section{1 전극촉매 제조}

$20 \mathrm{wt} \% \mathrm{Pt} / \mathrm{RuO}_{2}$ 와 $40 \mathrm{wt} \% \mathrm{Pt} / \mathrm{RuO}_{2}$ 나노선 촉매 전극을 제조하기 위하여 먼저 $\mathrm{RuO}_{2}$ 나노선 지지체를 전기방사법 에 의해 다음과 같이 제조하였다. $\mathrm{RuCl}_{3} \cdot \mathrm{xH}_{2} \mathrm{O}$ (Aldrich) 의 전구체를 12 시간 동안 $\mathrm{N}, \mathrm{N}$-dimethylformamide $(\mathrm{DMF}$, Aldrich) 안에 용해시켰다. 그리고 PVP (Poly(vinylpyrrolidone), Aldrich, $\mathrm{M}_{\mathrm{w}}=1,300,000 \mathrm{~g} / \mathrm{mol}$ ) 고분자를 N,N-dimethylformamide (DMF, Aldrich) 안에 $\mathrm{RuCl}_{3} \cdot \mathrm{xH}_{2} \mathrm{O}$ (Aldrich) 이 용해된 용액에 첨가시켰다. 이 용액을 상온에서 4시간 동안 잘 섞은 후 23 gauge 스테인레스 바늘이 장착된 syringe 속에 옮기었다. 그리고 나서 스텐인레스 바늘과 포 집판에 DC power supply (Powertron. Co., Ltd., Korea) 의 positive power와 ground를 각각 연결하였다. 전기방사 동안 용액의 feeding rate은 $0.01 \mathrm{ml} / \mathrm{h}$ 로 고정하였으며 나 노선을 포집하는 $\mathrm{Si}$ 기판은 $12 \mathrm{kV}$ 전압에서 syringe needle
로부터 $15 \mathrm{~cm}$ 거리에 수직으로 위치하였다. 이렇게 얻어 진 $\mathrm{RuO}_{2}$ 나노선 지지체는 2시간 동안 $80^{\circ} \mathrm{C}$ 에서 건조하 였고 공기 중에 2 시간 동안 $400^{\circ} \mathrm{C}$ 에서 열처리하였다. 우 선 $40 \mathrm{wt} \%$ 의 촉매가 담지 된 경우에 대해서 설명하면, 얻 어진 $\mathrm{RuO}_{2}$ 나노선 지지체를 $300 \mathrm{ml}$ 증류수에 1시간 동안 분산 시킨 후 $1.12 \mathrm{mM}$ Pt전구체 $\left(\mathrm{H}_{2} \mathrm{PtCl}_{6} \cdot \mathrm{xH}_{2} \mathrm{O}\right.$, Aldrich $)$ 를 용해시킨다. 환원제로써 $\mathrm{NaBH}_{4}$ (Aldrich)를 첨가한 후 30 분 동안 계속 교반 시켰다. 이렇게 얻어진 전극촉매를 여러 번 증류수로 세척한 후 $-60^{\circ} \mathrm{C}$ 에서 동결건조법에 의 해 최종 샘플을 얻었다. 또한 $20 \mathrm{wt} \%$ 의 촉매가 담지 된 경우에 대해서 설명하면, 위에 같은 방법에서 $0.56 \mathrm{mM}$ $\mathrm{Pt}$ 전구체를 사용하며 나머지 방법은 모두 동일하게 진 행하였다. 따라서 우리는 $20 \mathrm{wt} \% \mathrm{Pt} / \mathrm{RuO}_{2}$ 와 $40 \mathrm{wt} \% \mathrm{Pt} /$ $\mathrm{RuO}_{2}$ 전극촉매를 성공적으로 합성하였다. 일차원 나노선 전극촉매를 비교 평가하기 위해서 전기방사법에 의하여 electrospun Pt 나노선 전극촉매를 다음과 같은 조건으로 제조하였다. $\mathrm{Pt}$ 전구체 $\left(\mathrm{H}_{2} \mathrm{PtCl}_{6} \cdot \mathrm{xH}_{2} \mathrm{O}\right.$, Aldrich)를 2시간 동 안 증류수에 용해 시켰으며 PVP (Poly(vinylpyrrolidone), Aldrich, $\mathrm{M}_{\mathrm{w}}=1,300,000 \mathrm{~g} / \mathrm{mol}$ ) 고분자를 에탄올 용액에 5 시간 동안 용해 시켰다. 두 용액을 함께 섞은 후에 DC power supply (Powertron. Co., Ltd., Korea)에 연결하였 다. 전기방사 동안 용액의 feeding rate은 $0.02 \mathrm{ml} / \mathrm{h}$ 로 고 정하였으며 나노선을 포집하는 $\mathrm{Si}$ 기판은 $6.5 \mathrm{kV}$ 전압에서 syringe needle로부터 $8 \mathrm{~cm}$ 거리에 수직으로 위치하였다. 이렇게 얻어진 electrospun Pt 나노선 전극촉매는 공기 중 에 2 시간 동안 $400^{\circ} \mathrm{C}$ 에서 열처리하였다. 따라서 우리는 이러한 절차로 electrospun Pt 나노선 전극촉매를 성공적 으로 제조하였다.

\section{2 전극촉매의 구조 분석}

일차원 나노선 전극촉매의 구조와 형태 및 원소를 분 석하기 위하여 투과전자현미경(transmission electron microscope, TEM, TECNAI-F20) 및 EDS (energy-dispersive X-ray spectroscopy, EDS, EMAX Energy EX-250) 분석 을 수행하였다. 결정구조 분석은 $\mathrm{CuK}_{\alpha}$ source를 장착한 Rigaku x-ray diffractometer를 이용하여 X-선 회절분석(Xray diffraction, XRD, Rigaku Rint 2500)을 이용하였으며 $1 \%$ min의 속도로 $2 \theta=20 \sim 70^{\circ}$ 의 회절범위 안에서 측정하 였다. 또한 전극촉매의 조성과 화학결합상태를 분석하기 위하여 $\mathrm{AlK}_{\alpha}$ source를 장착한 $\mathrm{X}$-선 광전자 분광법(X-ray photoemission spectroscopy, XPS, ESCALAB 250)를 사 용하였으며 모든 데이터는 Gaussian-Lorentzian line-shape 와 Shirley baseline을 이용하여 Peak-fitting을 수행하였다.

\section{3 전극촉매의 전기화학적 특성 분석}

촉매들의 electrochemical activity 측정은 conventional 
three-electrode system을 이용하여 수행하였다. 보조전극과 기준전극은 $\mathrm{Pt}$ 전극과 $\mathrm{Ag} / \mathrm{AgCl}$ 전극을 사용하였다. 촉매와 Nafion (Aldrich) (8:2 wt\%)이 포함된 촉매 잉크를 micropipette을 이용하여 작업전극(glassy carbon, $0.706 \mathrm{~cm}^{2}$ )위 에 올렸고 $70^{\circ} \mathrm{C}$ 로 oven 안에서 건조시켰다. 또한 $2 \mathrm{M}$ $\mathrm{CH}_{3} \mathrm{OH}$ 와 $0.5 \mathrm{M} \mathrm{H}_{2} \mathrm{SO}_{4}$ 이 섞인 수용액을 전해질로 사용 하였다. 전기화학 실험 전에 test cells은 질소 가스를 이 용하여 정화하였으며 계속적으로 교반시켰다. Catalytic activity는 $-0.2-1.0 \mathrm{~V}$ 전압 범위에서 $50 \mathrm{mV} / \mathrm{s}$ 의 scan rate 으로 cyclic voltammetry (AUTOLAB by Eco Chemie)를 이용하여 측정하였다. 촉매의 electrochemically active surface (EAS) area 실험은 $0.5 \mathrm{M} \mathrm{H}_{2} \mathrm{SO}_{4}$ 수용액 안에서 -0.2 $-1.0 \mathrm{~V}$ 전압 범위와 $50 \mathrm{mV} / \mathrm{s}$ 의 scan rate으로 측정하였다.

\section{3. 결과 및 고찰}

Fig. 1(a)-1(d)은 (a) single- $\mathrm{RuO}_{2}$ 나노선 지지체, (b) 20 $\mathrm{wt} \% \mathrm{Pt} / \mathrm{RuO}_{2}$ 나노선 촉매, (c) $40 \mathrm{wt} \% \mathrm{Pt} / \mathrm{RuO}_{2}$ 나노선
촉매, (d) electrospun Pt 나노선 촉매의 bright-field TEM 이미지들을 나타낸다. Fig. 1(a)에 보이는 것처럼 우리는 전기방사법에 의하여 $\mathrm{RuO}_{2}$ 나노선 지지체를 제조하였다. 나노선 지지체의 직경은 약 $50 \mathrm{~nm}$ 정도이며 Fig. 1(a)에서 는 보여지지 않았지만 50 만 배 이상 관찰 시에 $4-7 \mathrm{~nm}$ 정도의 작은 나노 입자들로 구성되어 있음을 알 수 있 다. 또한 $\mathrm{RuO}_{2}$ 나노선 지지체의 표면은 거칠기 때문에 더 많은 Pt나노 입자 촉매들이 쉽게 담지 될 수 있다. Fig. 1 (b)와 1 (c)은 $\mathrm{RuO}_{2}$ 나노선 지지체에 침전법을 이용하여 $20 \mathrm{wt} \%$ 와 $40 \mathrm{wt} \%$ 의 Pt 나노 입자 촉매를 담지 시켰다. Bright-field TEM 이미지에서 보이는 것처럼 촉매 입자의 분포가 고르게 나타났다. 특히 $\mathrm{RuO}_{2}$ 나노선 지지체위에 성 장된 $\mathrm{Pt}$ 나노 입자의 크기는 50 만배 이상의 고분해능 관 찰을 통해 2-4 nm임을 확인하였다. 이러한 $\mathrm{Pt}$ 나노 촉매 의 균일한 분포는 연료전지의 성능에 영향을 끼친다. Fig. 1(d)은 electrospun Pt 나노선 촉매의 bright-field TEM 이 미지이며 나노선 촉매 전극의 비교평가를 위하여 제조하 였다. 상대적으로 거의 같은 dark contrast로 인하여 50 만

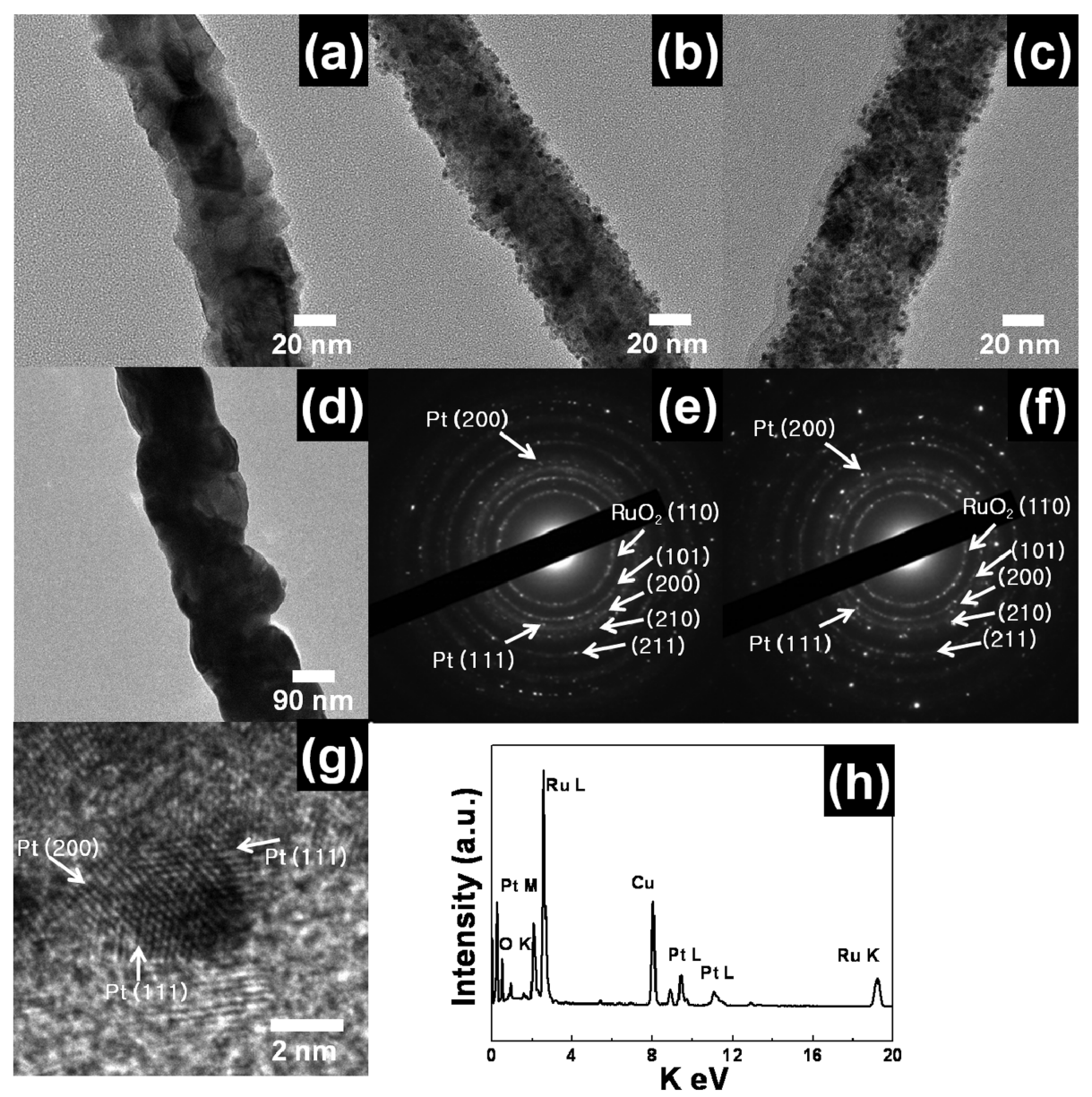

Fig. 1. Bright-field TEM images obtained from (a) electrospun $\mathrm{RuO}_{2}$ nanowires, (b) $20 \mathrm{wt} \% \mathrm{Pt} / \mathrm{RuO}_{2}$ nanowires, (c) $40 \mathrm{wt} \% \mathrm{Pt} / \mathrm{RuO} \mathrm{O}_{2}$ nanowires, (d) electrospun Pt nanowires, EDP data of (e) $20 \mathrm{wt} \% \mathrm{Pt} / \mathrm{RuO}_{2}$ nanowires and (f) $40 \mathrm{wt} \% \mathrm{Pt} / \mathrm{RuO}_{2}$ nanowires, (g) $\mathrm{HRTEM}$ images of $40 \mathrm{wt} \% \mathrm{PtRuO}_{2}$ nanowires and $\mathrm{EDS}$ data of (h) $40 \mathrm{wt} \% \mathrm{Pt} / \mathrm{RuO}_{2}$ nanowires. 
배 이상의 고분해능에서 관찰 하였을 때 순수한 Pt 나노 입자로 구성된 나노선이 형성되었음을 알 수 있다. Fig. 1(e)와 Fig. 1(f)에서 보여지듯이 $\mathrm{RuO}_{2}$ 나노선 지지체위에 담지된 $\mathrm{Pt}$ 나노 입자 촉매들의 결정구조를 전자회절패턴 (electron diffraction pattern, EDP)을 통해서 확인하였다. 특히 (e) $20 \mathrm{wt} \% \mathrm{Pt} / \mathrm{RuO}_{2}$ 와 (f) $40 \mathrm{wt} \% \mathrm{Pt}_{\mathrm{RuO}}$ 촉매의 경우 나노 입자 형성을 의미하는 (000) spot 주위에 diffraction ring 패턴이 관찰되었으며 각각의 diffraction pattern에 indexing을 수행하였다. 또한 Pt 나노 촉매 입자가 잘 형성 되었는지 확인하기 위하여 Fig. 1(g)에서 보이는 것처럼 HRTEM을 수행하였다. 즉 HRTEM 데이터에서 보 이는 것처럼 $\mathrm{Pt}$ 나노 입자는 $\sim 5 \mathrm{~nm}$ 이하의 단결정들이 중 첩되어 있음을 확인하였다. 더욱이 Fig. $1(\mathrm{f})$ 의 $40 \mathrm{wt} \% \mathrm{Pt} /$ $\mathrm{RuO}_{2}$ 촉매의 경우 Fig. 1(e)의 $20 \mathrm{wt} \% \mathrm{Pt} / \mathrm{RuO}_{2}$ 촉매에 비하여 더 많은 Pt 나노 촉매의 담지로 인하여 $\mathrm{Pt}$ (111) 와 (200)에 회절 점들이 증가 하였음을 확인하였다. Fig. $1(\mathrm{~h})$ 은 $40 \mathrm{wt} \% \mathrm{Pt} / \mathrm{RuO}_{2}$ 나노선 촉매의 $\mathrm{EDS}$ data를 보여 준다. $\mathrm{EDS}$ 결과는 정성적인 값으로서 샘플 안에 $\mathrm{Pt}$ 원자 와 $\mathrm{Ru}$ 원자가 존재함을 나타낸다. 따라서 $\mathrm{EDS}$ 결과와 더 불어 TEM data에서 확인된 것처럼 atomic fraction이 높 은 $\mathrm{Pt}$ 의 contrast는 상대적으로 검은색인 Pt nano-dot에 상 응하며 상대적으로 밝은 $\mathrm{Ru}$ 의 contrast는 나노선의 형태 를 갖는 내부에 상응한다. 다시 말해서 $\mathrm{Ru}$ 원자는 나노 선 안에 균일하게 존재하고(core부분) Pt 원자는 나노선의 가장 자리에 나노입자 형태로 존재하고 있다(shell부분). 참 고로 $\mathrm{EDS}$ 결과 내에 $\mathrm{Cu}$ peak는 TEM 시편 제조 시 사용 된 $\mathrm{Cu}$-grid에서 기인된 것으로 판단된다.

Fig. 2은 $\mathrm{RuO}_{2}$ 나노선 지지체, $20 \mathrm{wt} \% \mathrm{Pt} / \mathrm{RuO}_{2}$ 나노선 촉매, $40 \mathrm{wt} \% \mathrm{Pt} / \mathrm{RuO}_{2}$ 나노선 촉매 및 electrospun $\mathrm{Pt}$ 나 노선 촉매의 결정구조 분석을 위한 Powder XRD 데이터

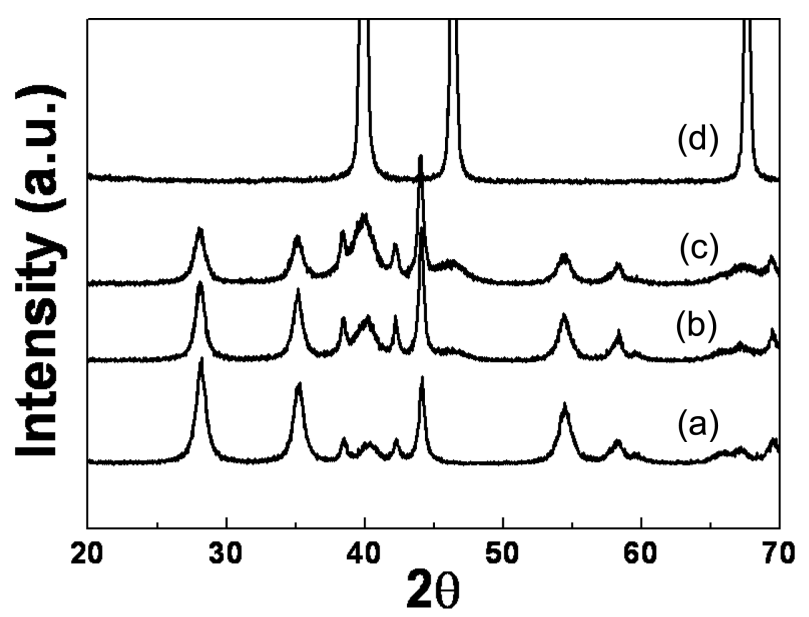

Fig. 2. Powder XRD data of (a) electrospun $\mathrm{RuO}_{2}$ nanowire support, (b) $20 \mathrm{wt} \% \mathrm{Pt} / \mathrm{RuO}_{2}$ nanowires, (c) $40 \mathrm{wt} \% \mathrm{PtRuO}_{2}$ nanowires and (d) electrospun Pt nanowires.
를 보여준다. $\mathrm{RuO}_{2}$ 나노선 지지체의 경우 $28.0^{\circ}, 35.0^{\circ}$, $54.2^{\circ}$ 의 $2 \theta$ 값에서 회절 피크를 나타냈고, 이는 tetragonal 결정구조를 갖는 $\mathrm{RuO}_{2}$ phases와 잘 일치함을 알 수 있다 (space group $\left.\mathrm{P}_{2} / \mathrm{mnm}[136]\right) . \mathrm{Pt}$ 나노 촉매의 경우 $39.7^{\circ}$, $46.2^{\circ}, 67.4^{\circ}$ 의 $2 \theta$ 값에서 $\mathrm{Pt}$ phases에 대한 회절 패턴이 나 타나고 이것은 합성한 Pt 나노 촉매가 FCC (face-centered cubic) 결정구조를 가진다는 것을 나타낸다(space group $\mathrm{Fm} 3 \mathrm{~m}[225])$. 더욱이 Scherrer equation을 이용하여 Pt 나노 입자의 사이즈를 알 수 있는데 본 연구에서는 Pt의 XRD 회절 피크들이 $\mathrm{RuO}_{2}$ 나노선 $\mathrm{XRD}$ 회절 피크 위에 중첩 이 되어 계산하기 어려우나 $\mathrm{Pt}$ 의 $46.2^{\circ}$ 에서 (200) plane 회절 피크를 관찰한 결과 반치폭(FWHM, $\beta$ )이 넓으므로 $\mathrm{Pt}$ 입자는 작은 사이즈의 나노 입자임을 알 수 있다. 이 러한 이유는 아래의 공식에서도 보여지는 것처럼 반치폭 (FWHM, $\beta$ )은 입자사이즈 (D)에 반비례하기 때문이다. 게 다가 $100 \mathrm{wt} \% \mathrm{Pt}$ 나노선 촉매의 경우 반치폭(FWHM, $\beta$ ) 이 좁으므로 아래의 식을 통해 촉매의 사이즈가 증가함을 알 수 있다. Scherrer equation은 다음과 같다.,10)

$$
\mathrm{D}=0.9 \lambda /(\beta \cos \theta)
$$

이때 $\lambda$ 는 $X$-선 파장, $\beta$ 는 반치폭, $\theta$ 는 브래그 각을 의 미 한다. 따라서 위의 공식을 이용하여 $20 \mathrm{wt} \% \mathrm{Pt} / \mathrm{RuO}_{2}$ 와 $40 \mathrm{wt} \% \mathrm{Pt} / \mathrm{RuO}_{2}$ 나노선 전극 촉매에 대한 Pt 나노 촉매의 평균 입자 크기 $(\mathrm{D})$ 는 $\sim 3 \mathrm{~nm} \pm 1 \mathrm{~nm}$ 정도로 계산되었다. 이 것은 bright-field TEM 및 $\mathrm{XRD}$ 결과와 잘 일치한다.

Fig. 3은 나노 촉매의 chemical bonding states를 규명하 기 위한 $\mathrm{Ru} 3 \mathrm{~d}$ core level 및 Pt 4f core level의 XPS 스펙트럼을 나타낸다. 모든 스펙트럼 피크들은 C 1s line $(284.5 \mathrm{eV})$ 을 이용하여 보정하였다. Fig. 3(a)에서 보여지는 것처럼 $\mathrm{Ru}_{3 / 2}$ 와 $\mathrm{Ru}_{5 / 2}$ photoelectrons에 대한 XPS 피 크들은 각각 $284.7 \mathrm{eV}$ 와 $280.5 \mathrm{eV}$ 에서 관찰되었다. 이 것은 $\mathrm{RuO}_{2}$ 안에 $\mathrm{Ru}$ 원자들이 $\mathrm{Ru}(\mathrm{IV})$ species로 존재함 을 의미한다. ${ }^{11)} \mathrm{Fig}$. 3(b)와 3(c)의 경우, $20 \mathrm{wt} \%$ 와 $40 \mathrm{wt} \%$ $\mathrm{Pt} / \mathrm{RuO}_{2}$ 나노선 촉매의 지지체인 $\mathrm{RuO}_{2}$ 또한 $\mathrm{Ru}(\mathrm{IV})$ species로 존재함을 확인하였다. Fig. 3(d)와 Fig. 3(e)은 $20 \mathrm{wt} \% \mathrm{Pt} / \mathrm{RuO}_{2}$ 및 $40 \mathrm{wt} \% \mathrm{Pt} / \mathrm{RuO}_{2}$ 나노선 촉매의 $\mathrm{Pt}$ $4 \mathrm{f}_{5 / 2}$ 와 Pt $4 \mathrm{f}_{7 / 2}$ photoelectrons에 대한 XPS 피크들이 74.5 $\mathrm{eV}$ 와 $71.2 \mathrm{eV}$ 에서 관찰되었음을 보여준다. 게다가 Fig. 3(f)은 electrospun Pt 나노선 촉매의 Pt $4 \mathrm{f}_{5 / 2}$ 와 $\mathrm{Pt} 4 \mathrm{f}_{7 / 2}$ photoelectrons에 대한 XPS 피크들 역시 $\sim 74.5 \mathrm{eV}$ 와 71.2 $\mathrm{eV}$ 에서 관찰되었음을 나타낸다. 이것은 다시 말해 $\mathrm{Pt}$ 나 노 촉매의 경우 $\mathrm{Pt}(0)$ states즉, 금속 상으로 존재함을 의 미한다. ${ }^{11)}$ 또한 Pt $4 \mathrm{f}$ core level의 경우 두 쌍의 doublet 으로 구성되어 있고 doublet의 두 번째 쌍은 $~ 75.7 \mathrm{eV}$ 와 $\sim 72.3 \mathrm{eV}$ 에서 관찰되었다. 이것은 $\operatorname{Pt}(0)$ states보다 더 높 은 에너지에서 관찰 되었으며 $\mathrm{PtO}$ 나 $\mathrm{Pt}(\mathrm{OH})_{2}$ 같은 $\mathrm{Pt}(\mathrm{II})$ 

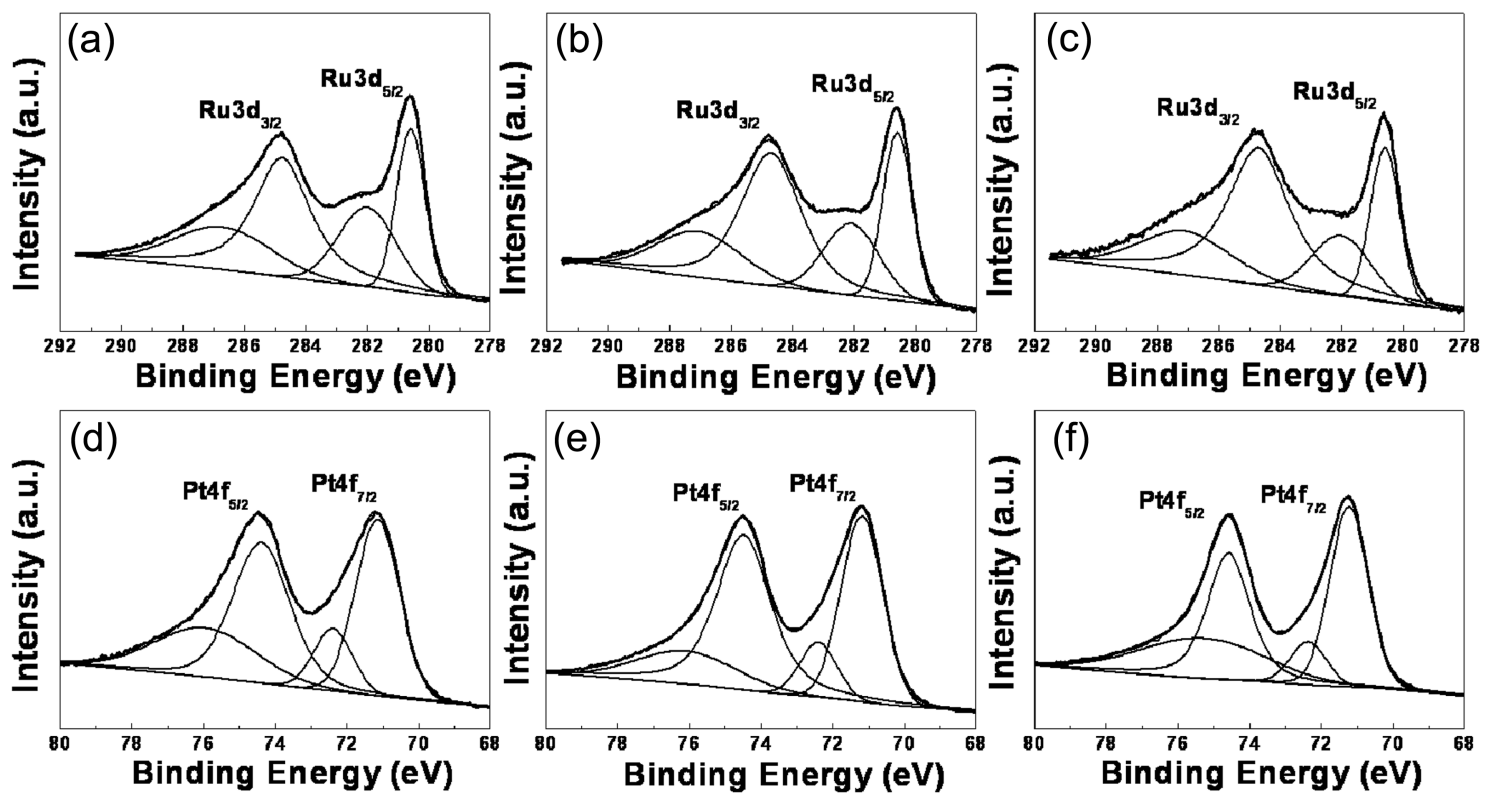

Fig. 3. XPS spectra of $\mathrm{Ru} 3 \mathrm{~d}$ obtained from (a) $\mathrm{RuO}_{2}$ nanowire support, (b) $20 \mathrm{wt} \% \mathrm{Pt} / \mathrm{RuO}_{2}$ nanowires, and (c) $40 \mathrm{wt} \% \mathrm{Pt} / \mathrm{RuO} \mathrm{O}_{2}$ nanowires and the $\mathrm{Pt} 4 \mathrm{f}$ obtained from (d) $20 \mathrm{wt} \% \mathrm{Pt} / \mathrm{RuO}_{2}$ nanowires, (e) $40 \mathrm{wt} \% \mathrm{Pt} / \mathrm{RuO}_{2}$ nanowires and (f) electrospun $\mathrm{Pt}$ nanowires.

states와 관계된다. ${ }^{12)}$ 이것은 $\mathrm{Pt} 4 \mathrm{f}$ XPS 결과 $\mathrm{PtO}$ 나 $\mathrm{Pt}$ $(\mathrm{OH})_{2}$ 같은 Pt-oxide states가 Pt 나노 촉매 위에 존재 함 을 알 수 있다. 아마도 XPS 측정 동안 샘플의 공기 중 노출과 Pt 나노 촉매의 합성 시에 수용액에서의 산소가 Ptoxide states 형성을 야기시킨 것으로 판단된다. 이러한 Ptoxide states는 연료전지 측정 시 촉매의 활성을 저하시킬 수 있다. 하지만 XPS 피크의 면적을 비교하였을 때 Ptoxide states는 Pt-metallic states와 비교할 때 현저히 적은 양이므로 $\mathrm{Pt}$ 나노 촉매의 경우 oxide-states가 존재함에도 불구하고 좋은 산화거동을 나타낸다. 따라서 methanol electro-oxidation에 대한 Pt나노 입자의 금속성 표면 상태 는 산화물 상태보다 더욱 활성적이며 안정하기 때문에 좋 은 연료전지 효율을 얻을 수 있다.

Fig. 4은 (a) electrospun Pt나노선 촉매, (b) $20 \mathrm{wt} \% \mathrm{Pt} /$ $\mathrm{RuO}_{2}$ 나노선 촉매 및 (c) $40 \mathrm{wt} \% \mathrm{Pt} / \mathrm{RuO}_{2}$ 나노선 촉매들 의 methanol electro-oxidation에 대한 전압과 전류밀도 데 이터를 나타낸다. 이것을 측정하기 위하여 두 샘플의 cyclic voltammogram $(\mathrm{CV})$ 은 $50 \mathrm{mV} / \mathrm{s}$ 의 scan rate와 함께 -0.2 $\mathrm{V}-1.0 \mathrm{~V}$ 전위범위에서 측정하였다. Methanol oxidation을 위한 샘플들의 촉매 활성화를 측정하기 위하여 $2.0 \mathrm{M}$ $\mathrm{CH}_{3} \mathrm{OH}$ 와 $0.5 \mathrm{M} \mathrm{H}_{2} \mathrm{SO}_{4}$ 를 섞은 수용액을 사용하였다. 이 전 연구에서 보고 된 것처럼 methanol은 anode에서 물과 반응해서 6 protons, 6 electrons, $\mathrm{CO}_{2}$ 를 생성한다. ${ }^{13)}$

$$
\mathrm{CH}_{3} \mathrm{OH}+\mathrm{H}_{2} \mathrm{O} \rightarrow \mathrm{CO}_{2}+6 \mathrm{H}^{+}+6 \mathrm{e}^{-}
$$

따라서 효율적인 methanol electro-oxidation은 anode에서 electrons의 효율적인 생산을 의미한다. 이것은 직접 메탄
올 연료전지의 더 좋은 효율을 나타낸다. Methanol electrooxidation의 효율은 forward process 안에서 anodic current density에 의해서 쉽게 평가 될 수 있다. 참고로 methanol electro-oxidation 동안 모든 샘플들의 cyclic voltammogram (CV)은 forward 피크와 backward 피크로 구성된 두 가 지 다른 피트들이 나타낸다. Forward 피크는 anodic current density와 backward 피크는 $\mathrm{CH}_{2} \mathrm{OH}, \mathrm{CHO}, \mathrm{HCOOH}$ and $\mathrm{CO}$ 와 같은 intermediate species와 관계된다. Forward 피 크는 $\sim 0.68 \mathrm{~V}$ 이며 backward 피크는 $\sim 0.45 \mathrm{~V}$ 을 의미한다. 즉 다시 말하면 높은 anodic current density는 촉매의 높

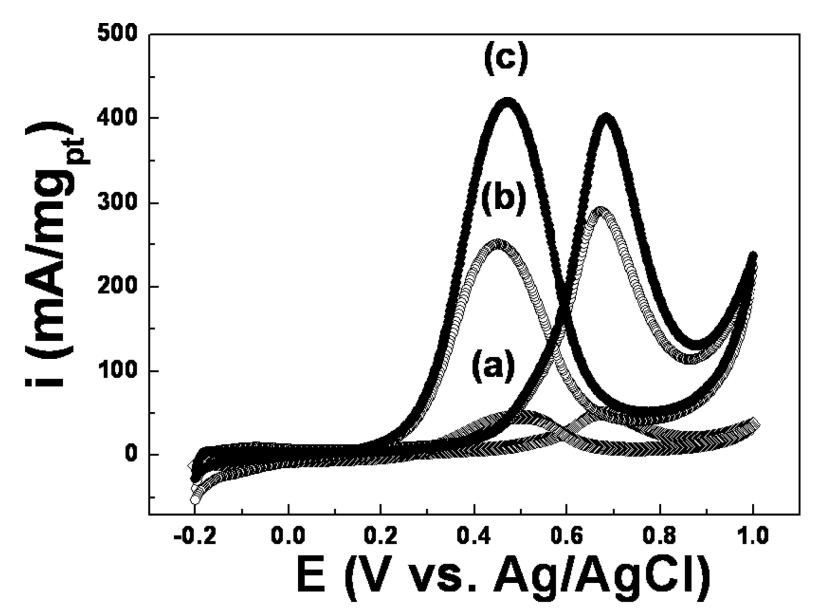

Fig. 4. Cyclic Voltammograms (CVs) for methanol electro-oxidation of (a) electrospun Pt nanowires, (b) $20 \mathrm{wt} \% \mathrm{Pt} / \mathrm{RuO}_{2}$ nanowires and (c) $40 \mathrm{wt} \% \mathrm{Pt} / \mathrm{RuO}_{2}$ nanowires measured at scan rate of $50 \mathrm{mV} / \mathrm{s}$ in the range of -0.2 to $1.0 \mathrm{~V}$ (in a mixture of $0.5 \mathrm{M} \mathrm{H}_{2} \mathrm{SO}_{4}$ and $2 \mathrm{M}$ $\left.\mathrm{CH}_{3} \mathrm{OH}\right)$. 


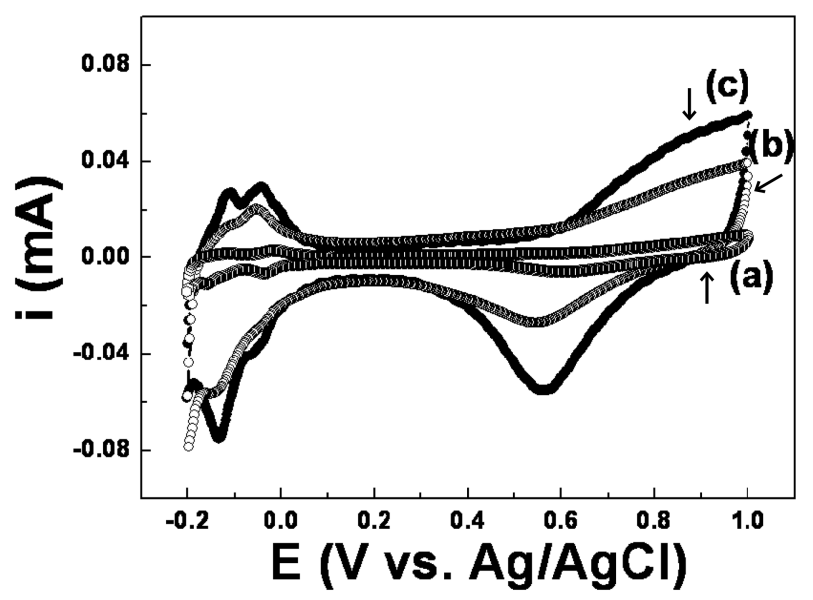

Fig. 5. Cyclic Voltammograms (CVs) of (a) electrospun Pt nanowires, (b) $20 \mathrm{wt} \% \mathrm{Pt} / \mathrm{RuO}_{2}$ nanowires and (c) $40 \mathrm{wt} \% \mathrm{Pt} / \mathrm{RuO}_{2}$ nanowires for electro-adsorption and desorption of $\mathrm{H}_{2}$ at scan rate of $50 \mathrm{mV} / \mathrm{s}$ in the range of -0.2 to $1.0 \mathrm{~V}$ (in aqueous solution of $0.5 \mathrm{M} \mathrm{H}_{2} \mathrm{SO}_{4}$ ).

은 효율을 나타낸다. 따라서 electrospun Pt나노선 촉매, $20 \mathrm{wt} \% \mathrm{Pt} / \mathrm{RuO}_{2}$ 나노선 촉매, $40 \mathrm{wt} \% \mathrm{Pt} / \mathrm{RuO}_{2}$ 나노선 촉 매의 current density값들은 $0.68 \mathrm{~V}$ 에서 $47.3 \mathrm{~mA} / \mathrm{g}, 290.0$ $\mathrm{mA} / \mathrm{g}, 400.8 \mathrm{~mA} / \mathrm{g}$ 의 값을 각각 나타내는데, 이것은 20 $\mathrm{wt} \% \mathrm{Pt} / \mathrm{RuO}_{2}$ 나노선 촉매와 $40 \mathrm{wt} \% \mathrm{Pt} / \mathrm{RuO}_{2}$ 나노선 촉 매가 electrospun Pt 나노선 촉매에 비하여 높은 효율 향 상을 보임을 의미한다. 다시 말해, 전기방사에 의해 제조 된 $\mathrm{RuO}_{2}$ 나노선 지지체위에 담지된 $\mathrm{Pt}$ 나노 촉매의 경 우 순수한 Pt 나노선 촉매에 비하여 우수한 촉매 효율을 가짐을 나타낸다. 또한 $\mathrm{Pt}$ 나노 촉매의 더 많은 담지량으 로 인하여 $40 \mathrm{wt} \% \mathrm{Pt} / \mathrm{RuO}_{2}$ 나노선 촉매의 경우 $20 \mathrm{wt} \%$ $\mathrm{Pt} / \mathrm{RuO}_{2}$ 나노선 촉매 보다 1.4배 정도 효율향상을 확인하 였다. Fig. 5은 촉매 활성화를 더욱더 규명하기 위하여 $\mathrm{CH}_{3} \mathrm{OH}$ 가 없는 $0.5 \mathrm{M} \mathrm{H}_{2} \mathrm{SO}_{4}$ 수용액에서 Electrochemically active surface area (EAS)를 측정하였다. Cyclic voltammogram $(\mathrm{CV})$ 에서 이중층을 제외한 $-0.2 \mathrm{~V}$ 에서 0.0 $\mathrm{V}$ 안에 수소 탈착 면적을 이용하여 $\mathrm{EAS}$ area을 구할 수 있다. ${ }^{14)}$ 이러한 방법을 통해 (a) electrospun Pt 나노선 촉 매, (b) $20 \mathrm{wt} \% \mathrm{Pt} / \mathrm{RuO}_{2}$ 나노선 촉매, (c) $40 \mathrm{wt} \% \mathrm{Pt} / \mathrm{RuO}_{2}$ 나노선 촉매의 $\mathrm{EAS}$ 값이 각각 $0.0016 \mathrm{~cm}^{2}, 0.036 \mathrm{~cm}^{2}, 0.052$ $\mathrm{cm}^{2}$ 임을 관찰하였다. 이것은 $20 \mathrm{wt} \% \mathrm{Pt} / \mathrm{RuO}_{2}$ 나노선 촉 매 및 $40 \mathrm{wt} \% \mathrm{Pt} / \mathrm{RuO}_{2}$ 나노선 촉매의 경우 electrospun $\mathrm{Pt}$ 나노선 촉매보다 우수한 EAS을 나타내고 있으며, 이 러한 결과들은 전기방사법에 의해 제조된 $\mathrm{RuO}_{2}$ 나노선 지 지체 위에 담지된 Pt 나노 촉매가 직접메탄올 연료전지용 anode 전극 촉매로써 사용이 가능하다는 것을 의미한다. 최근에 나노선의 활발한 연구에도 불구하고 본 연구결과 에서 보여지는 것처럼 연료전지의 경우 electrospun Pt 나 노선 촉매의 효율은 높지 않다. 이러한 구조에 비하여 지 지체와 나노 촉매의 core-shell 같은 구조들이 더욱 연료
전지의 촉매효율을 향상 시킬 수 있을 것이다. 현재 우 리 그룹은 Pt 나노 촉매의 더 높은 활성화를 위하여 다 공성의 $\mathrm{RuO}_{2}$ 지지체 같은 더욱 발전적인 구조들을 연구 중에 있다.

\section{4. 결 론}

본 연구에서는 직접메탄올 연료전지용 일차원 나노선 촉매를 제조하기 위하여 전기방사법과 침전법을 활용하 였다. $20 \mathrm{wt} \% \mathrm{Pt} / \mathrm{RuO}_{2}$ 나노선 촉매와 $40 \mathrm{wt} \% \mathrm{Pt} / \mathrm{RuO}_{2}$ 나 노선 촉매를 성공적으로 제조 하였으며 일차원 나노선 촉매 효율들을 비교하기 위하여 electrospun Pt 나노선 촉 매와 비교 평가하였다. 더욱이 $40 \mathrm{wt} \% \mathrm{Pt} / \mathrm{RuO}_{2}$ 나노선 촉 매는 다른 촉매 전극들과 비교하였을 때 높은 EAS 값과 우수한 촉매 활성도가 관찰되었다. 따라서 전기방사법에 의해 제조된 $\mathrm{RuO}_{2}$ 나노선 지지체위에 담지된 $\mathrm{Pt}$ 나노 입 자 촉매가 직접메탄올 연료전지를 위한 우수한 전극 촉 매 중 하나가 될 것 이라 판단된다.

\section{참 고 문 헌}

1. A. S. Arico, S. Srinivasan and V. Antonucci, Fuel Cells, 1, 133 (2001).

2. S. Yoo, S. M. Kang, J. Lee, C. K. Rhee and H. Ryu, Kor. J. Mater. Res. 21(3). 180 (2011) (in Korean).

3. M. Winter and R. J. Brodd, Chem. Rev., 104, 4245 (2004).

4. H. -J. Ahn, W. J. Moon, T. -Y. Seong and D. Wang, Electrochem. Comm., 11, 635 (2009).

5. K. -W. Park and Y. -E. Sung, J. Ind. Eng. Chem., 12, 165 (2006).

6. H. -J. Ahn, H. -S. Shim, W. B. Kim, Y. E. Sung and T. -Y. Seong, J. Alloy. Comp., 471, L39 (2009).

7. H. -J. Ahn, J. -S. Jang, Y. E. Sung and T. -Y. Seong, J. Alloy. Comp., 473, L28 (2009).

8. S. Barth, F. Hernandez-Ramirez, J. D. Holmes and A. Romano-Rodriguez, Progr. Mater. Sci., 55, 563 (2010).

9. H. -J. Ahn, H. -C. Choi, K. -W. Park, S. -B. Kim and Y. -E. Sung, J. Phys. Chem. B, 108, 9815 (2004).

10. X. Ye, J. Sha, Z. Jiao and L. Zhang, Nanostruct. Mater., 8, 919 (1997).

11. J. F. Moulder, W. F. Stickle, P. E. Sobol and K. D. Bomben, Handbook of X-ray Photoelectron Spectroscopy, p.114115, p.180-181, Physical Electronics, Eden Pairie, MN, U.S.A (1995).

12. Z. Liu, L. Hong and S. W. Tay, Mater. Chem. Phys., 105, 222, (2007).

13. B. R. Rauhe, F. R. Mclarnon and E. J. Cairns, J. Electrochem. Soc., 142, 1073 (1995).

14. A. Pozio, M. De Francesco, A. Cemmi, F. Cardellini and L. Giorgi, J. Power Sourc., 105, 13 (2002). 